\title{
Parking and competition for space in urban neighborhoods: Residents' perceptions of traffic and parking-related conflicts
}

\author{
Franziska Kirschner \\ Goethe University Frankfurt/Main \\ kirschner@geo.uni-frankfurt.de
}

\begin{abstract}
The infrastructure for parking and parked cars themselves (e.g., parked cars blocking bike lanes and sidewalks or the visibility range) can lead to conflicts for pedestrians and cyclists. The perception of conflicts could discourage walking and cycling in neighborhoods and undermine municipalities' efforts to provide more sustainable urban mobility. The aim of this study was therefore to analyze the effect of on-street car parking in urban neighborhoods on perceived parking and traffic-related conflicts. In addition, it examines in what way the intention to reduce one's car use influences the perception of the conflicts (Stage Model of Self-Regulated Behavior Change (SSBC)). A household survey was conducted in the inner-city neighborhood of FrankfurtBornheim, Germany ( $\mathrm{N}=1027)$. The residents most often observed the conflicts in which parked cars impeded walking and cycling as well as situations in which pedestrians felt threatened by cyclists biking on the sidewalk. Results from multiple linear regression models revealed that the influencing factors for the perception of conflicts were the use of different means of transportation and the intention to change one's behavior (SSBC model) to reduce car use rather than car ownership. In addition, a resident's age and household structure seemed to affect awareness of conflicts in which pedestrians and cyclists were involved. The results suggest a group-serving bias, meaning that the residents mostly observed those conflicts that they did not cause. A separate infrastructure for pedestrians and cyclists could help prevent most of the conflicts described in this study.
\end{abstract}

\section{Article history:}

Received: August 6, 2020

Received in revised form:

December 6, 2020

Accepted: February 7, 2021

Available online: June 8, 2021

\section{Introduction}

Present planning for car-oriented cities has led to a car-dependent transport system in most North American and European cities. They contain a high amount of car and parking infrastructure as well as high levels of private car ownership (Mattioli, Roberts, Steinberger, \& Brown, 2020). When most travel is carried out by cars, the resulting traffic congestion compromises the efficiency of the transportation system and the city's quality of life (Vuchic, 2010). Furthermore, car-oriented cities usually neglect pedestrian infrastructure and offer ample free parking (Chester, Horvath, \& Madanat, 2011; Manville \& Pinski, 2020; Weinberger \& Jacobson, 2014).

In urban areas the number of people who regularly use alternatives to the private car is increasing

Copyright 2021 Franziska Kirschner

http://dx.doi.org/10.5198/jtlu.2021.1870

ISSN: 1938-7849 | Licensed under the Creative Commons Attribution - Noncommercial License 4.0

The Journal of Transport and Land Use is the official journal of the World Society for Transport and Land Use (WSTLUR) and is published and sponsored by the University of Minnesota Center for Transportation Studies. 
steadily. Yet, land allocation and infrastructure for active travel mostly stays at the same level (Infas \& DLR, 2019; Kuhnimhof, Buehler, Wirtz, \& Kalinowska, 2012; Le, Buehler, \& Hankey, 2019). The infrastructure for parking and parked cars themselves can be a conflict risk for pedestrians and cyclists as many accidents in the US involve parked cars (Schlossberg \& Amos, 2015). The risk of accidents varies between different types of neighborhoods, i.e., whether they are areas characterized by high or low residents' vehicles miles travelled (Merlin, Cherry, Mohamadi-Hezaveh, \& Dumbaugh, 2020). In addition, the risk increases on local roads with low visibility, for instance at intersections (Becker, 2016; Bracher, 2014; Findley et al., 2020). Moreover, the land consumption of parked cars can lead to conflicts between traffic participants and they can represent a danger to pedestrians when vehicles cross sidewalks to get to parking lots or parking garages. Parked cars can also increase the separating effect of streets because they hinder the crossing of roads for pedestrians, for people with luggage, and for cyclists. Furthermore, parking supply affects residents' decision about car ownership and car use (Chester et al., 2011; Manville \& Shoup, 2018; Notz, 2017; Vuchic, 2010; Weinberger, 2018; Weinberger \& Jacobson, 2014). In addition, in a literature review from studies across the world, Jacobsen, Racioppi, and Rutter (2009) discovered that the perception of the risks of conflicts may discourage residents from walking and cycling. This again leads to car use and, consequently, to cars that need to be parked. Notz (2017) points out that while the importance of sustainable mobility and recognizing public space is gaining momentum, parked cars are not problematized in public discourse in Germany but are rather seen as a necessary normality.

Therefore, the aim of this research is to analyze empirically the effect of on-street car parking in urban neighborhoods on perceived parking and traffic-related conflicts. Here, conflicts are defined as threatening and dangerous situations between traffic participants from the perspective of the participants. If we know more about the perception of the conflicts, we can better evaluate the implications the conflicts have on different resident groups and their mobility behavior. The paper looks at car parking as one form of land use by examining how urban space is currently used and whether this leads to conflicts with subsequent consequences.

Thus, a household survey $(\mathrm{N}=1027)$ in an inner-city neighborhood in Frankfurt, Germany, was conducted to answer the following research questions: (1) To what extent do residents perceive different parking and traffic-related conflicts? (2) In what way does car and bike ownership, and the use intensity of different means of transportation influence the perception of the conflicts? (3) How do the car-owning residents, who park their cars in the neighborhood, perceive the conflicts? (4) In what way does the intention to reduce car use influence the perception of the conflicts? Building upon other studies, which worked with the Stage Model of Self-Regulated Behavior Change (SSBC), and which showed that the intention towards reduced car use reveals a differentiation between car owners (e.g., Blitz, Busch-Geertsema, \& Lanzendorf, 2020; Kirschner \& Lanzendorf, 2020a), this analysis assesses whether this intention has an influence as well. In addition, the influence of five control variables on the perception are analyzed (gender, age, household structure, income, university degree).

Subsequently, the hypotheses to be tested are the following: Residents observe parking-related conflicts between different traffic participants (H1). Car ownership has an influence on the perception of the conflicts (H2). Bike ownership has an effect on the perception of conflicts (H3). Differences in the usage rates of means of transportation affect awareness of the conflicts (H4). The residents who own cars and need to park these perceive the conflicts differently from residents who live car-free (H5). Classification into the SSBC model produces differences in the perception of conflicts (H6).

This paper is structured as follows: after a review of the literature about space allocation and the perception of risk and conflicts, the case study and methods are presented in section 3. Section 4 covers the results of the perception of conflicts in general, of the findings of the multivariate analysis regarding 
all households and the classification into the SSBC model, as well as the results for the residents with car ownership. Finally, section 5 discusses the findings and closes with conclusions.

\section{State of the art}

\subsection{Space allocation in urban neighborhoods}

Urban space is a scarce resource. Different means of transportation have different requirements and so they compete for the urban space. Pedestrians and their way of using public space (walking, strolling, or staying in a place to talk) are in competition for space with moving and parked cars (Alrutz \& Bohle, 2001; Norton, 2008). In addition, although pedestrians and cyclists have in common a long neglection from planning due to car-oriented urban planning, but because of their different infrastructure needs, they are still in competition with each other for (a high quality of) road space and political attention (Banister, 2008; Bracher, 2014; Litman, 2019). Compared to cars, pedestrians and cyclists require less space to move and, in the case of cycling, for parking. According to Norton (2008), the current arrangement of street space is the result of a technical and social reconstruction of the street for the car. Most cities coped with the increasing number of vehicle traffic in the 20th century by using open public space for roads and for parking vehicles. Spaces that were once areas for pedestrians were often turned into parking lots. However, parking requirements and especially large parking areas impede the potentially different uses of public roads and lead to a loss of the pedestrian scale (Bracher, 2014; Gehl, 2010; Jacobsen et al., 2009).

On the other hand, cities can move parking to central garages at the edge of a neighborhood or underground to recapture traffic space as social space and design neighborhood streets almost completely car free (Dürr \& Simon-Philipp, 2013). Moreover, by eliminating subsidized and free parking in central areas and excluding parking on sidewalks, cities can create attractive pedestrian areas and extend the bike lane network (Goldman \& Gorham, 2006; Vuchic, 2010). In conclusion, due to diverging interests, a well-used public space is also always a conflictual space (Dürr \& Simon-Philipp, 2013). However, currently, the multi-functionality of public space in urban neighborhoods (traffic, residential environment, communication platform) is not visible in its allocation for different uses as parked cars use public space disproportionately to the modal split (Gössling, Schröder, Späth, \& Freytag, 2016; Nello-Deakin, 2019). Pedestrians and cyclists, on the other hand, may save space, help reduce air pollution, and thereby contribute to the quality of life in a neighborhood (Gehl, 2015; Notz, 2017).

\subsection{Motorized traffic and parking as a safety risk}

Safety problems on the road started around 100 years ago. Before the arrival of the car, pedestrians and cyclists were able to use the whole street but this situation changed when motorized cars arrived in the city and neighborhood streets, and fatalities became frequent. Most of the victims were pedestrians and cyclists, and a majority of those were children and young people (Cox, 2012; Jacobsen et al., 2009; Norton, 2008).

Today, we still face similar problems. In the US, motor vehicle accidents with moving and parked cars account for half of all accidental deaths, and, in Germany, there are more than 3,000 yearly traffic deaths (Federal Statistical Office, 2020; Gifford \& Steg, 2007). Pedestrians and cyclists are at risk in particular. For instance, pedestrians account for a higher percentage of traffic fatalities in the US than their share of road use. In addition, speed differentials between modes have a profound effect on the safety of pedestrians and cyclists (Culver, 2018; Ewing \& Dumbaugh, 2009). Moreover, the likelihood to be involved in a crash depends on the type of neighborhood and its destination accessibility (Merlin 
et al., 2020). In sprawling neighborhoods, the overall fatality rates and the rate of pedestrian fatalities are higher than in denser areas, where the average speeds are lower and the uninterrupted length of a roadway is shorter. In other words, overall, narrow streets with a slow speed are safer for pedestrians and cyclists (Ewing \& Dumbaugh, 2009; Malin, Silla, \& Mladenović, 2020). However, many accidents to pedestrians in these fabrics happen while trying to cross a street or a road (Malin et al., 2020). The risk of accidents increases with low visibility, for instance, due to parked cars or during parking maneuvers (Bracher, 2014; Findley et al., 2020). For example, more than two-thirds of accidents on local streets in the US involve parked cars that were parked on-street (Schlossberg \& Amos, 2015). Especially at intersections, parked cars lead to reduced visibility for all traffic participants. Thus, one part of parking management is to ban parking around intersections as to increase the visibility of pedestrians and cyclists for car drivers (Becker, 2016). Furthermore, a cause of incidents between cyclists and vehicles is so-called dooring. This happens when passengers open vehicle doors into the path of cyclists without looking over their shoulder (Ewing \& Dumbaugh, 2009; Pai, 2011).

\subsection{The perception of risks among different groups}

Particular risk groups are children and older people. Drivers miss seeing children, especially when they dart out from between parked cars. Older people tend to avoid perceived unsafe areas with high traffic, such as unmarked crosswalks (as opposite of zebra crossings), and they cannot react as quickly anymore when obstacles are on the sidewalk (Ewing \& Dumbaugh, 2009; Harms et al., 2009; Jacobsen et al., 2009). Harms et al. (2009) observed that, apart from the elderly, people from car-free households have the highest perception of risk with respect to parked cars and cyclists on sidewalks as they feel like parked cars take away their pedestrian space. In addition, they discovered that the subjective perception of risks on sidewalks is not necessarily congruent with the amount of counted (near) collisions in different areas within a neighborhood. Furthermore, Chataway, Kaplan, Nielsen, and Prato (2014) studied the safety perceptions from different modes. They reported the behavior of cyclists in mixed traffic, focusing on infrastructure and coping strategies. Several studies explore the safety of infrastructure with a focus on visibility in moving traffic, e.g., perceived risk in bike-car interactions (Chaurand \& Delhomme, 2013), and perceived risk with low visibility conditions (King, Wood, Lacherez, \& Marszalek, 2012; Wood, Lacherez, Marszalek, \& King, 2009).

In conclusion, a real and perceived risk of conflicts with moving and parked cars may discourage walking and cycling in neighborhoods (Jacobsen et al., 2009). Although fatalities caused by motorizedtraffic are well known and documented in governmental statistics, they are seldom problematized. Culver (2018) calls the violence of the car a "blind spot" (p. 146) in transportation and mobility research. So far, most studies analyzed conflict perceptions in moving traffic, and perceived safety of infrastructure layouts or risk potentials under low visibility (e.g., Chataway at al., 2014; Chaurand \& Delhomme, 2013; King et al., 2012; Wood et al., 2009). This study tries to shed new light on traffic participants' conflict perceptions with a focus on parking, specifically on parking in urban neighborhoods.

\section{$3 \quad$ Materials and methods}

\subsection{Case study}

The neighborhood of Bornheim is the case study of this household survey. It is centrally located in the city of Frankfurt, and, with approximately 30,000 inhabitants, it is among the neighborhoods with the highest population densities in the city (City of Frankfurt, 2019a). At the time of the survey, on-street parking was unlimited in most parts of the neighborhood without any time or financial restrictions. 
In the southern part, there was a parking scheme with residential parking permits. Such permits cost twenty-five euros per year. The scheme states, however, that not all on-street parking spaces are reserved for permit holders, but, instead, fifty percent of the available on-street parking space still needs to be accessible in an unlimited way (Kirschner \& Lanzendorf, 2020b). In the meanwhile, the administration implemented a neighborhood wide parking concept, which extends the current regulations to the whole neighborhood (City of Frankfurt, 2019b). In terms of alternative means of transportation, the neighborhood is well served by multiple subway, tram, and bus lines that connect the neighborhood to the central station. Several officially designated bike lanes run through the neighborhood. Furthermore, there are carsharing and bike sharing stations throughout the neighborhood. The speed limit is $50 \mathrm{~km} / \mathrm{h}$ $(\approx 30 \mathrm{mph})$ on main roads in cities and $30 \mathrm{~km} / \mathrm{h}(\approx 19 \mathrm{mph})$ for residential streets.

The sample reveals that almost forty percent of households in the neighborhood do not own a private car (Table 1). In comparison, in Germany as a whole, twenty percent of households live car-free, and we find the highest number (forty percent) in the main cities (Infas \& DLR, 2019). Of the sixty percent of households with private cars in Bornheim, around half of them park their cars off-street in their own parking spaces or in garages and another fifty percent uses on-street parking as well as the residential parking permits. In addition, residents show high rates of walking, the majority regularly uses public transit, and there is a similar usage rate for cars and bicycles. Although the car is not the main means of transportation among residents in the neighborhood, as in similar central neighborhoods of other cities, parked cars dominate the image of the streets and, often, of the sidewalks as well (Figure 1). The mean occupancy rate of on-street parking space in the neighborhood differs for each street and is between 75\% and over 90\% (measured between 6am and 10pm; City of Frankfurt, 2014). On-street parking does not automatically legally include fully parking on the sidewalk as shown in Figure 1 in the photo on the left. Only in some streets it is legally allowed. However, in almost all parts of the neighborhood, cars partially park on the sidewalk to fit into the street size and width. The width of the sidewalks differs between $2 \mathrm{~m}$ in mostly residential streets and up to $7 \mathrm{~m}$ in the main connecting roads throughout the neighborhood (City of Frankfurt, 2020).

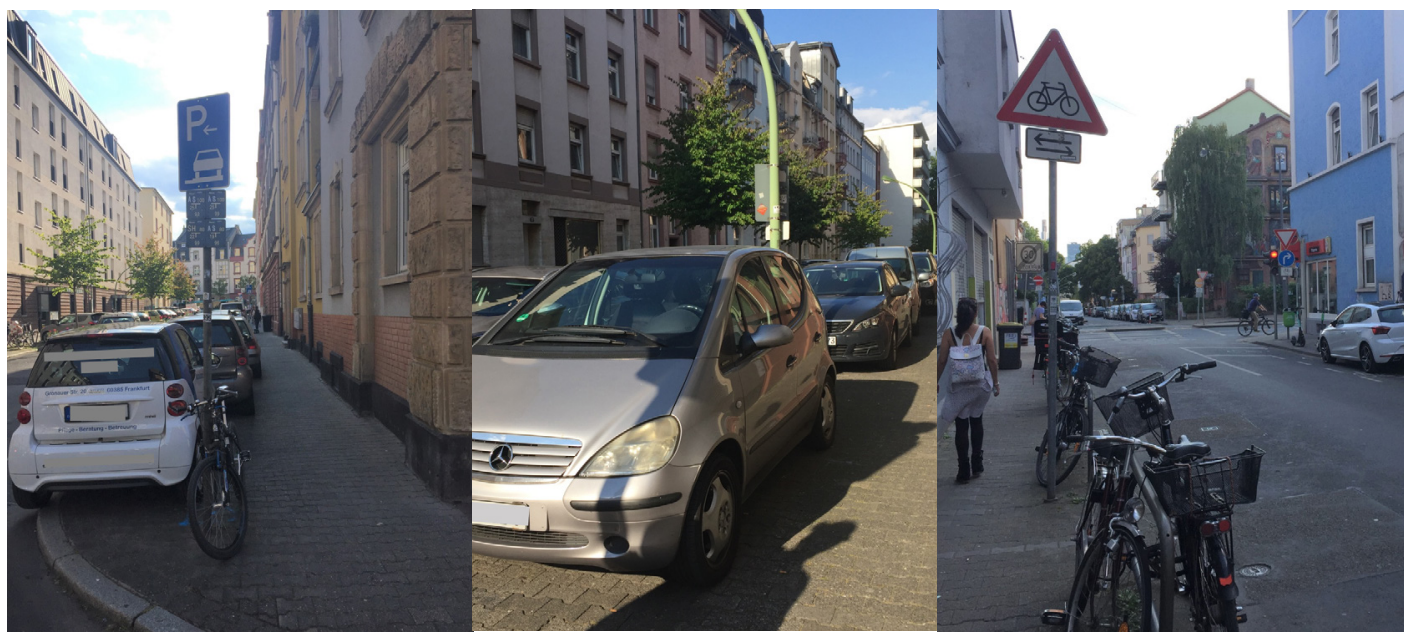

Figure 1. Impressions of the case study of Frankfurt-Bornheim (photos by author)

Regarding socio-demographics, in comparison to available data statistics for the neighborhood and the whole city, our sample has a higher percentage of female participants, older people, and large households (Table 2). 
Table 1. Descriptive statistics of mobility-related variables used for the analysis $(\mathrm{N}=1027)$

\begin{tabular}{|c|c|c|c|}
\hline Variable & Description & Mean & SD \\
\hline \multicolumn{4}{|l|}{ Ownership } \\
\hline Households without car ownership & No $\operatorname{car}(1) ; \geq 1$ car $(0)$ & 0.39 & 0.488 \\
\hline Private bicycle ownership & No (0); yes (1) & 0.72 & 0.448 \\
\hline \multicolumn{4}{|l|}{ Transport modes: Regularl users of ... } \\
\hline$\ldots$ private car as driver & Non-regular use (0); regular use (1) & 0.45 & 0.498 \\
\hline ... public transit & Non-regular use (0); regular use (1) & 0.67 & 0.471 \\
\hline ... bicycle & Non-regular use $(0)$; regular use (1) & 0.47 & 0.499 \\
\hline$\ldots$ walking $^{2}$ & $\begin{array}{l}\text { At a non-regular level }(0) \text {; at a regular } \\
\text { level (1) }\end{array}$ & 0.88 & 0.324 \\
\hline \multicolumn{4}{|c|}{ Residential parking (residents from car owning households only, $N=627$ ) } \\
\hline \multirow[t]{2}{*}{ Users of residential on-street parking } & $\begin{array}{l}\text { Own parking space and rented off-street } \\
\text { parking }(0) \text {; }\end{array}$ & \multirow[t]{2}{*}{0.56} & \multirow[t]{2}{*}{0.497} \\
\hline & on-street parking and parking permit (1) & & \\
\hline \multicolumn{4}{|l|}{${ }^{1}$ Regular use: (almost) daily - 1-3 days/week } \\
\hline${ }^{2}$ We excluded walking from further multiv & to high walking rates and low variation. & & \\
\hline
\end{tabular}

Table 2. Socio-demographic statistics of variables used for the analysis ( $\mathrm{N}=1027)$ in comparison to available city statistics

\begin{tabular}{|c|c|c|c|c|c|}
\hline \multicolumn{2}{|l|}{ Socio-demographics } & \multicolumn{2}{|c|}{ Sample } & \multirow{2}{*}{$\frac{\text { Bornheim }}{\text { Mean }}$} & \multirow{2}{*}{$\frac{\text { Frankfurt }}{\text { Mean }}$} \\
\hline Variable & Description & Mean & SD & & \\
\hline Gender: male* & Female (0); male (1) & 0.40 & 0.49 & 0.47 & 0.50 \\
\hline Mean age*1 & Age in years (18-92) & 50.5 & 15.5 & 42.7 & 40.8 \\
\hline University degree & No (0); yes (1) & 0.55 & 0.49 & no data & no data \\
\hline Families with children $* 2$ & $\begin{array}{l}\text { Families without children }(0) \text {; families } \\
\text { with children (1) }\end{array}$ & 0.16 & 0.36 & 0.15 & 0.18 \\
\hline \multirow{2}{*}{$\begin{array}{l}\text { Net monthly income (mean } \\
\text { value } 200-6.000 €)^{3}\end{array}$} & Income in Euro & $2,299.41$ & 1129.48 & no data & no data \\
\hline & & \multicolumn{2}{|c|}{$\mathrm{N}=1,027$} & $\mathrm{~N}=30,533$ & $\mathrm{~N}=747,848$ \\
\hline
\end{tabular}

*Significant difference between sample and total population of Bornheim, and total population of city of Frankfurt; binomial test, $\mathrm{p}<.001$

${ }^{1}$ Note that the age of the survey participants is $\geq 18$ years while the base for the mean age of Bornheim and the city of Frankfurt starts at aged 0 .

${ }^{2}$ Note that "children" in the survey is defined as being $<14$ years while the city administration does not define whether the threshold is at $<14$ or at $<18$ years.

${ }^{3}$ Quotient of the mean value of the monthly net household income (using the levels: less than $1000 €, 1000 €$ to less than $2500 €$, $2500 €$ to less than $4000 €, 4000 €$ to less than $5500 €, 5500 €$ and more) and the number of household members (adjusted according to the OECD-modified scale (OECD, 2016): value of first adult $=1.0$, each further adult $=0.5$, each child under 14 years $=0.3(\mathrm{OECD})$ 


\subsection{Data}

The household survey was part of a larger project about persistency and change in urban neighborhoods. The survey was cross-sectional and we conducted it in March 2018. 3,000 surveys were distributed and the return rate was thirty-four percent $(\mathrm{N}=1027)$. I used random route sampling and the last birthday method for distribution and household selection (Binson, Canchola, \& Catania, 2000; Diekmann, 2017; Fuller, 2009; Kirschner, 2019). The survey included six blocks: life in Bornheim, availability of means of transportation, frequency of use of means of transportation, mobility in Bornheim, policy options in Bornheim, and socio-demographics.

To measure parking and traffic-related conflicts in the neighborhood, the structure of the conflict items was based on Harms et al. (2009), who conducted a survey about parking in a neighborhood in Leipzig, Germany. The items directly or indirectly relate to conflicts with parked cars. Those items, which do not include parked cars in their description but solely pedestrians and cyclists, are related to parking indirectly via the land that has been dedicated to parked cars. First, I measured the items for the perceived conflicts using a five point Likert-type scale ranging from "strongly agree" to "strongly disagree."

Second, I conducted a principal component analysis (PCA) for the twenty-one conflict items. The PCA analysis revealed four factors with eigenvalues greater than one (Table 3). Factor 1 "Pedestrians are impeded by car traffic and parking" describes conflicts pedestrians may experience due to parked cars. Factor 2 "Cyclists are vulnerable with respect to car traffic and parking" is analogous to factor 1 and includes conflicts with and due to parked cars perceived from a cyclist's perspective. The third factor "Pedestrians are impeded by bicycles on the sidewalk" is composed of conflicts pedestrians have with cyclists and bike racks on the sidewalk. The fourth factor "Car drivers' perceived conflicts with others" are conflicts, perceived from the car drivers' view, with other traffic participants, i.e., other car drivers, pedestrians, and cyclists.

Third, to analyze the intention to change one's behavior, I use the stage model of self-regulated behavior change (SSBC) (Bamberg, 2012, 2013). It includes the theory of planned behavior (Ajzen, 1991) and the norm activation model (Schwartz, 1977) and is based on the transtheoretical model (DiClemente \& Prochaska, 1982; Prochaska \& DiClemente, 1983). Alongside car and bicycle ownership as well as regular use of different means of transportation (Table 1), the aim is to assess whether the intention to reduce personal car use has an influence on the perception of the conflicts. The SSBC understands behavior change as a process of four stages. While residents in stage one are currently satisfied with their behavior and see no reason to change, residents in the fourth stage already use their private car less often and instead use other means of transportation. I assign residents who live in households without private cars to the residents in the postactional stage, as their car use is low as well and as they mostly make use of public transit and bicycles (see Kirschner \& Lanzendorf, 2020a, for a detailed description).

To assign the residents into the four stages, as part of the survey, the participants were asked to indicate their personal assessment with a 5 point Likert scale of nine different questions (Figure 2). Each question referred to an underlying construct as part of one of the stages (Bamberg, 2012). The final classification of the residents into the four stages are shown in Figure 3. 


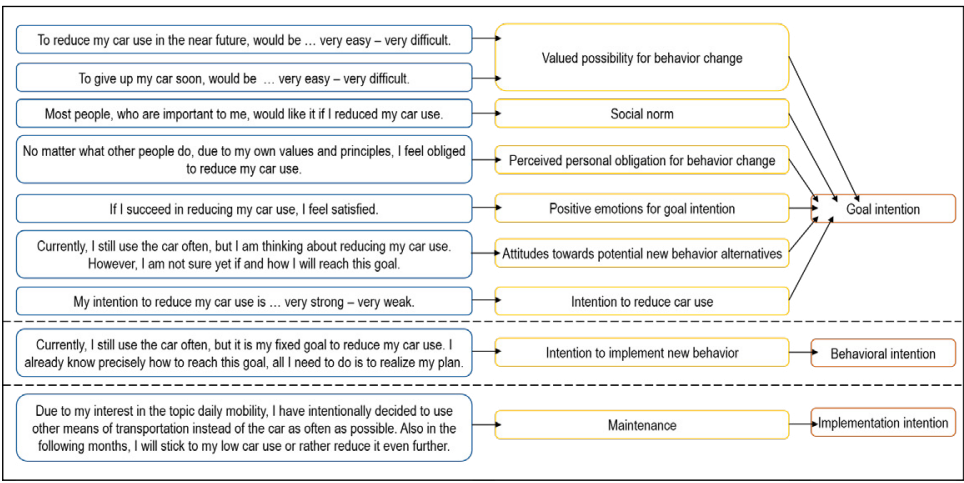

Figure 2. Questions for the stage assignment of the SSBC model (based on Bamberg, 2012)

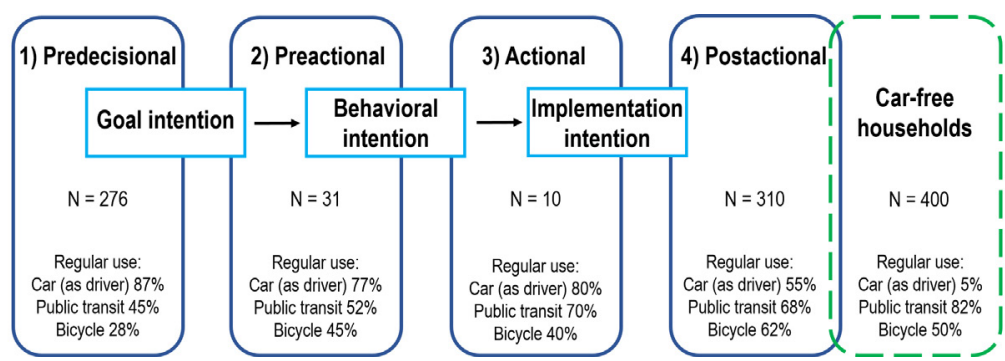

Figure 3. Stage model of self-regulated behavior change towards reduced private car use; shown are the classification of survey participants into each stage, as well as each car, public transit, and bicycle usage rate (own diagram, based on Bamberg, 2013)

\section{$4 \quad$ Results}

\subsection{The perception of parking and traffic-related conflicts of residents in an urban neighborhood}

Table 3 shows the perception of conflicts for each of the twenty-one conflict items. The conflicts the residents observe most often are those in which parked cars impede walking and cycling, as well as when pedestrians feel threatened by cyclists who bike on the sidewalk. The conflict items the residents perceive least often are when bicycle parking lots are on sidewalks and the overall risk of an accident as a pedestrian. In addition, the residents observe individual conflict items of the factor "Car drivers' perceived conflicts with others" the least often compared to the other three factors. The factor "Cyclists are vulnerable with respect to car traffic and parking" consists of the individual conflict items which the residents are aware of most often. 
Table 3. Principal component analysis and initial items of perceived parking and traffic-related conflicts in the neighborhood $(\mathrm{N}=1027)$

\begin{tabular}{|c|c|c|c|c|c|c|}
\hline \multirow[b]{2}{*}{$\begin{array}{l}\text { Items regarding perceived conflicts } \\
\text { Items measured on a five point Likert } \\
\text { scale: (1) strongly agree - (5) strongly } \\
\text { disagree } \\
\text { In Bornheim ... }\end{array}$} & \multirow[b]{2}{*}{ Mean } & \multirow[b]{2}{*}{ SD } & \multicolumn{4}{|c|}{ Factors } \\
\hline & & & $\begin{array}{l}\text { Pedestrians } \\
\text { are impeded } \\
\text { by car traffic } \\
\text { and parking }\end{array}$ & $\begin{array}{l}\text { Cyclists are } \\
\text { vulnerable } \\
\text { with respect } \\
\text { to car traffic } \\
\text { and parking }\end{array}$ & $\begin{array}{l}\text { Pedestrians } \\
\text { are impeded } \\
\text { by bicycles on } \\
\text { the sidewalk }\end{array}$ & $\begin{array}{c}\text { Car drivers' } \\
\text { perceived } \\
\text { conflicts with } \\
\text { others }\end{array}$ \\
\hline $\begin{array}{l}\ldots \text { as a pedestrian, parked cars often } \\
\text { impede walking. }\end{array}$ & 2.81 & 1.16 & .831 & .249 & .026 & -.017 \\
\hline $\begin{array}{l}\ldots \text { as a pedestrian, I often have to } \\
\text { change my path because cars park on } \\
\text { the sidewalk. }\end{array}$ & 3.00 & 1.18 & .815 & .238 & .044 & -.016 \\
\hline $\begin{array}{l}\text {... as a pedestrian, parked vehicles are } \\
\text { a safety risk because approaching cars } \\
\text { cannot see me easily when I want to } \\
\text { cross the street. }\end{array}$ & 3.08 & 1.15 & .714 & .297 & .094 & .107 \\
\hline $\begin{array}{l}\ldots \text { as a pedestrian, I often feel vulner- } \\
\text { able with respect to car drivers, who } \\
\text { do not pay attention to pedestrians } \\
\text { while parking. }\end{array}$ & 3.42 & 1.02 & .698 & .251 & .195 & .081 \\
\hline $\begin{array}{l}\ldots \text { it is difficult to walk with a buggy, } \\
\text { walking aid or a suitcase because } \\
\text { sidewalks are not lowered. }\end{array}$ & 2.97 & 1.07 & .679 & .043 & .114 & .131 \\
\hline $\begin{array}{l}\text {.. parked cars increase the risk of an } \\
\text { accident for pedestrians and cyclists. }\end{array}$ & 2.98 & 1.12 & .663 & .337 & .027 & -.068 \\
\hline $\begin{array}{l}\ldots \text { risk of an accident as a pedestrian } \\
\text { is high. }\end{array}$ & 3.67 & 0.99 & .655 & .066 & .247 & .088 \\
\hline ... many sidewalks are too narrow. & 2.94 & 1.14 & .651 & .107 & .115 & .095 \\
\hline $\begin{array}{l}\ldots \text { as a pedestrian, I often feel vulner- } \\
\text { able at intersections when I want to } \\
\text { cross an intersection straight ahead } \\
\text { and cars want to make a turn. }\end{array}$ & 3.28 & 1.06 & .621 & .304 & .114 & .171 \\
\hline $\begin{array}{l}\ldots \text { as a cyclist, I often feel vulnerable } \\
\text { with respect to car drivers, who do not } \\
\text { pay attention to cyclist while parking. }\end{array}$ & 2.94 & 1.29 & .187 & .854 & -.044 & .072 \\
\hline $\begin{array}{l}\ldots \text { as a cyclist, I often feel vulnerable } \\
\text { at intersections when I want to cross } \\
\text { an intersection straight ahead and cars } \\
\text { want to make a turn. }\end{array}$ & 3.00 & 1.26 & .164 & .842 & -.038 & .096 \\
\hline $\begin{array}{l}\ldots \text { as a cyclist, parked vehicles are a } \\
\text { safety risk because approaching cars } \\
\text { cannot see me easily when I want to } \\
\text { cross the street. }\end{array}$ & 3.13 & 1.32 & .251 & .829 & .001 & .076 \\
\hline $\begin{array}{l}\ldots \text { as a cyclist, I often have to change } \\
\text { my route because cars are parked on } \\
\text { the bike lane. }\end{array}$ & 2.96 & 1.29 & .254 & .813 & -.062 & .019 \\
\hline ... often, parked cars impede cycling. & 2.90 & 1.27 & .306 & .803 & -.072 & .015 \\
\hline $\begin{array}{l}\ldots \text { as a cyclist, the risk of accidents } \\
\text { is high. }\end{array}$ & 3.07 & 1.22 & .158 & .729 & .057 & .011 \\
\hline
\end{tabular}




\begin{tabular}{|c|c|c|c|c|c|c|}
\hline \multirow[b]{2}{*}{$\begin{array}{l}\text { Items regarding perceived conflicts } \\
\text { Items measured on a five point Likert } \\
\text { scale: (1) strongly agree - (5) strongly } \\
\text { disagree } \\
\text { In Bornheim ... }\end{array}$} & \multirow[b]{2}{*}{ Mean } & \multirow[b]{2}{*}{ SD } & \multicolumn{4}{|c|}{ Factors } \\
\hline & & & $\begin{array}{l}\text { Pedestrians } \\
\text { are impeded } \\
\text { by car traffic } \\
\text { and parking }\end{array}$ & $\begin{array}{l}\text { Cyclists are } \\
\text { vulnerable } \\
\text { with respect } \\
\text { to car traffic } \\
\text { and parking }\end{array}$ & $\begin{array}{l}\text { Pedestrians } \\
\text { are impeded } \\
\text { by bicycles on } \\
\text { the sidewalk }\end{array}$ & $\begin{array}{l}\text { Car drivers' } \\
\text { perceived } \\
\text { conflicts with } \\
\text { others } \\
\end{array}$ \\
\hline $\begin{array}{l}\ldots \text { as a pedestrian, I get annoyed } \\
\text { by bicycles that are parked on the } \\
\text { sidewalk. }\end{array}$ & 3.45 & 1.29 & .202 & .012 & .875 & .018 \\
\hline $\begin{array}{l}\ldots \text { as a pedestrian, I do not welcome } \\
\text { bicycle parking lots on the sidewalk. }\end{array}$ & 3.83 & 1.22 & .104 & -.043 & .871 & .011 \\
\hline $\begin{array}{l}\ldots \text { as a pedestrian, cyclists, who bike } \\
\text { on the sidewalk, threaten me. }\end{array}$ & 2.87 & 1.27 & .242 & -.076 & .733 & .013 \\
\hline $\begin{array}{l}\text {... I sometimes get in conflicts with } \\
\text { other car drivers who are also search- } \\
\text { ing for a parking lot. }{ }^{a}\end{array}$ & 3.89 & 0.87 & .006 & .035 & .030 & .755 \\
\hline $\begin{array}{l}\ldots \text { as a driver, I sometimes get in con- } \\
\text { flicts with pedestrians or cyclists. }{ }^{a}\end{array}$ & 3.90 & 0.87 & .101 & .025 & .182 & .688 \\
\hline $\begin{array}{l}\text {.. I sometimes get the feeling I hin- } \\
\text { der other people with my parked car. }{ }^{a}\end{array}$ & 4.04 & 0.80 & .153 & .102 & -.183 & .584 \\
\hline Eigenvalues & & & 7.3 & 3 & 1.5 & 1.5 \\
\hline$\%$ of variance & & & 35 & 14.2 & 7.1 & 6.9 \\
\hline Total explained variance & & & & 63 & $2 \%$ & \\
\hline \multicolumn{7}{|c|}{$\begin{array}{l}\text { PCA with varimax rotation; eigenvalues }>1 \text {; loadings } \leq 0.4 \text { shown in grey; Kaiser's criterion }=0.900 \text {; Bartlett's test of Sphe- } \\
\text { ricity: } \mathrm{X}^{2}=7327.8, \mathrm{df}=210, \mathrm{p}=0.000 ; \mathrm{N}=1027 \text { (Field, 2018; Stevens, 2002). }\end{array}$} \\
\hline${ }^{a}$ Only residents from car ownings householc & answered & questic & We replaced mis & ing values with & the mean value. & \\
\hline
\end{tabular}

\subsection{The effect of residents' characteristics on the perception of parking and traffic-related conflicts}

Following the previous analysis, I assess to what extent resident characteristics have an effect on the perception of the conflict factors: the intention to change one's behavior to reduce car use (SSBC), the ownership of cars and bikes, the regular use of different means of transportation, and socio-demographics as control variables (Table 4). The factors "Pedestrians are impeded by car traffic and parking" and "Cyclists are vulnerable with respect to car traffic and parking" are more frequently mentioned by residents in the postactional stage of the SSBC model of car use, residents from households without private cars and residents who regularly cycle. Residents in the predecisional stage and those who regularly drive, on the other hand, observe these conflicts less often. In addition, regular public transit users notice the conflicts between pedestrians and car traffic more often than the residents who do not regularly use public transit. Residents who own bicycles observe the conflicts between cyclists and car drivers more frequently but not the conflicts between pedestrians and cyclists. Furthermore, residents in the preactional and actional stages as well as regular car users more often observe conflicts from a car drivers' perspective, whereas residents in the postactional stage perceive those less frequently. Moreover, the data reveals that older residents perceive the conflicts pedestrians experience more frequently than the conflicts between cyclists and car drivers. Families with children more frequently observe the conflicts pedestrians and cyclists may have with cars but less often the conflicts between pedestrians and cyclists. 
Table 4. Mean value comparison of the perception of conflicts for different resident groups

\begin{tabular}{|c|c|c|c|c|}
\hline & $\begin{array}{l}\text { Pedestrians are } \\
\text { impeded by } \\
\text { car traffic and } \\
\text { parking } \\
\mathrm{N}=1027 \\
\end{array}$ & $\begin{array}{l}\text { Cyclists are } \\
\text { vulnerable with } \\
\text { respect to car traf- } \\
\text { fic and parking } \\
\mathrm{N}=1027\end{array}$ & $\begin{array}{l}\text { Pedestrians are } \\
\text { impeded by } \\
\text { bicycles on the } \\
\text { sidewalk } \\
\mathrm{N}=1027\end{array}$ & $\begin{array}{l}\text { Car drivers' per- } \\
\text { ceived conflicts } \\
\text { with others } \\
\mathrm{N}=1027\end{array}$ \\
\hline \multicolumn{5}{|l|}{ Stages of the SSBC model } \\
\hline Predecisional stage & $-0.39^{* *}$ & $-0.26^{* *}$ & $0.31^{* *}$ & 0.10 \\
\hline Preactional and actional stages & 0.07 & -0.01 & 0.10 & $0.55^{* *}$ \\
\hline Postactional stage & $0.15^{* *}$ & $0.10^{* *}$ & $-0.13^{* *}$ & $-0.07^{* *}$ \\
\hline \multicolumn{5}{|l|}{ Ownership } \\
\hline Households with car ownership & $-0.14^{* *}$ & $-0.06^{*}$ & 0.03 & 0.03 \\
\hline Households without car ownership & $0.22^{* *}$ & $0.09^{*}$ & -0.05 & -0.04 \\
\hline Private bicycle ownership & -0.01 & $0.22^{* *}$ & $-0.17^{* *}$ & -0.00 \\
\hline No private bicycle ownership & 0.04 & $-0.56^{* *}$ & $0.44^{* *}$ & 0.00 \\
\hline \multicolumn{5}{|l|}{ Regular use of means of transportation } \\
\hline Car as a driver & $-0.22^{* *}$ & $-0.09^{* *}$ & $0.09^{* *}$ & $0.96^{* *}$ \\
\hline Public transit & $0.04^{*}$ & -0.01 & -0.01 & -0.00 \\
\hline Bicycle & $0.10^{* *}$ & $0.27^{* *}$ & $-0.39^{* *}$ & 0.00 \\
\hline \multicolumn{5}{|l|}{ Socio-demographics } \\
\hline Gender (male) & 0.05 & -0.01 & 0.05 & -0.06 \\
\hline Gender (female) & -0.03 & 0.00 & -0.03 & 0.04 \\
\hline Age (18-29 years) & $-0.27^{*}$ & 0.10 & -0.18 & 0.16 \\
\hline Age (30-64 years) & 0.02 & $0.08^{* *}$ & $-0.12^{* *}$ & 0.00 \\
\hline Age (65+ years) & $0.17^{* *}$ & $-0.34^{* *}$ & $0.49^{* *}$ & -0.07 \\
\hline Families with children $<14$ years & $0.17^{*}$ & $0.22^{* *}$ & $-0.33^{* *}$ & 0.01 \\
\hline Families without children $<14$ years & $-0.03^{*}$ & $-0.04^{* *}$ & $0.06^{* *}$ & -0.00 \\
\hline Net monthly income $(<1.000 €)$ & 0.11 & $-0.18^{*}$ & $0.20^{*}$ & 0.06 \\
\hline Net monthly income $(1000 €$ to $<2.500 €)$ & 0.03 & 0.05 & 0.04 & 0.02 \\
\hline Net monthly income $(2.500 €$ to $<4.000 €)$ & -0.04 & 0.01 & -0.07 & -0.04 \\
\hline Net monthly income (> 4.000€) & -0.16 & -0.05 & $-0.23^{*}$ & -0.05 \\
\hline University degree & $-0.06^{*}$ & $0.13^{* *}$ & $-0.22^{* *}$ & $0.06^{*}$ \\
\hline No university degree & $0.07^{*}$ & $-0.16^{* *}$ & $0.27^{* *}$ & $-0.07^{*}$ \\
\hline All residents & 0.00 & 0.00 & 0.00 & 0.00 \\
\hline
\end{tabular}

Second, using multiple linear regression analyzes $(\mathrm{OLS})^{1}$, according to the research questions, I tested how the different ownership and use of different means of transportation, as well as the behavior change intention affected the perception of the conflicts. The explained variances vary between the

\footnotetext{
${ }^{1}$ Each model was tested for multicollinearity. The models were adequate, with Pearsons' correlation coefficient $<0.8$, tolerance value $>0.1$, and variance inflation factor < 10 (Backhaus et al., 2018; Cohen et al., 2003).
} 
models, with the highest for the conflicts that pedestrians experience with cyclists on the sidewalk and the lowest for "Car drivers' perceived conflicts with others" (Table 5).

Residents who are in the postactional stage tend to perceive the conflicts pedestrians and cyclists may have with car traffic and parking more often than residents who are in any of the other stages of the model. On the other hand, these residents in the postactional stage notice less often the conflicts, which occur when pedestrians feel impeded on the sidewalk by cyclists, and the conflicts car drivers may experience. Not owning a private car does not affect the probability of perceiving any of the conflicts in these models. Owning a bicycle more often affects the perception of the conflicts cyclists may have with car traffic and parking. Regarding the regular use of different means of transportation, the regular use of public transit is not critical for awareness of the conflicts in this case study, whereas the use of a car as a driver and the use of a bicycle appear to contrarily influence the perception of the conflicts around pedestrians.

Finally, regarding the control variables, an older age decreases the possibility of observing the conflicts cyclists may experience with cars. Besides, residents who live in households with children observe the situations pedestrians experience with car traffic and parked cars more than those living without children.

Table 5. OLS regression models for parking and traffic-related conflicts in the neighborhood

\begin{tabular}{|c|c|c|c|c|}
\hline & $\begin{array}{l}\text { Pedestrians are } \\
\text { impeded by } \\
\text { car traffic and } \\
\text { parking }\end{array}$ & $\begin{array}{c}\text { Cyclists are } \\
\text { vulnerable } \\
\text { with respect to } \\
\text { car traffic and } \\
\text { parking }\end{array}$ & $\begin{array}{l}\text { Pedestrians are } \\
\text { impeded by } \\
\text { bicycles on the } \\
\text { sidewalk }\end{array}$ & $\begin{array}{c}\text { Car drivers' } \\
\text { perceived } \\
\text { conflicts with } \\
\text { others }\end{array}$ \\
\hline \multicolumn{5}{|c|}{ Stages of SSBC [Reference: households with car ownership, stages 1-3] } \\
\hline $\begin{array}{l}\text { Households with and without car ownership in } \\
\text { postactional stage }(1=\text { yes; } 0=\text { no })\end{array}$ & $0.103^{* *}$ & $0.089^{* *}$ & $-0.136^{* * *}$ & $-0.113^{* *}$ \\
\hline \multicolumn{5}{|l|}{ Ownership } \\
\hline Households without car ownership $(1=$ yes; 0 = no) & 0.065 & 0.056 & 0.027 & 0.065 \\
\hline Private bicycle ownership $(1=$ yes; $0=$ no $)$ & -0.045 & $0.307^{* * *}$ & -0.031 & -0.014 \\
\hline \multicolumn{5}{|l|}{ Regular ${ }^{l}$ use of means of transportation } \\
\hline Car as a driver $(1=$ yes; $0=$ no $)$ & $-0.099^{* *}$ & -0.017 & 0.035 & 0.087 \\
\hline Public transit $(1=$ yes; $0=$ no $)$ & 0.008 & -0.018 & 0.022 & 0.036 \\
\hline Bicycle $(1=$ yes; $0=$ no $)$ & $0.104^{* *}$ & 0.042 & $-0.262^{* * *}$ & 0.023 \\
\hline \multicolumn{5}{|l|}{ Socio-demographics } \\
\hline Gender ( 1 = male; 0 = female $)$ & $0.070^{* *}$ & -0.009 & $0.048^{*}$ & $-0.054^{*}$ \\
\hline Age & $0.146^{* * *}$ & $-0.061^{*}$ & $0.187^{* * *}$ & -0.053 \\
\hline \multicolumn{5}{|l|}{ Families with children $<14$ years } \\
\hline$(1=$ yes; $0=$ no $)$ & $0.129^{* * *}$ & 0.024 & $-0.050^{*}$ & -0.019 \\
\hline Net monthly income & 0.006 & $-0.070^{* *}$ & -0.044 & -0.055 \\
\hline University degree $(1=$ yes; $0=$ no $)$ & -0.051 & $0.063^{*}$ & $-0.096^{* *}$ & $0.074^{* *}$ \\
\hline $\mathrm{R}^{2}$ & 0.102 & 0.157 & 0.223 & 0.029 \\
\hline corrected $\mathrm{R}^{2}$ & 0.092 & 0.147 & 0.214 & 0.019 \\
\hline F-statistic & $0.000^{* * *}$ & $0.000^{* * *}$ & $0.000^{* * *}$ & $0.001^{* *}$ \\
\hline $\mathrm{N}$ & 1027 & 1027 & 1027 & 1027 \\
\hline \multicolumn{5}{|c|}{$\begin{array}{l}\text { Factors from PCA analysis as dependent variables. Beta coefficients are shown. } \\
{ }^{* * *} \mathrm{p}<0.00,{ }^{* *} \mathrm{p}<0.05,{ }^{*} \mathrm{p}<0.10\end{array}$} \\
\hline
\end{tabular}




\subsection{Conflicts of residents with private car ownership}

The classification of residents with private cars into the different stages of intention to change one's behavior towards reduced car use has broadened the results of earlier studies. It is also of interest for this study to analyze these residents in detail because they are the residents who park their cars in the neighborhood and thus may cause some of the conflicts discussed here. The analysis has so far shown that while there is no difference in the conflict perception between residents with and without private cars, the perception distinction within car-owning households differs along the classification into the SSBC model. Therefore, in the following section, I analyze the conflict awareness of the residents from households with private car ownership in detail.

When comparing the mean values of the conflict items with those of all residents (Table 6), there are no changes in the significances for the SSBC stages and for bicycle ownership. Yet, there are differences between all residents and those with car ownership for the perception of the conflicts regarding the usage rates of cars and bicycles. The awareness of the conflicts "Pedestrians are impeded by car traffic and parking" is lowered among regular bike users when comparing it to the average of all residents, but it is still above the average of the residents with private cars only. Moreover, the perception of regular car users of the conflicts "Cyclists are vulnerable with respect to car traffic and parking" is not significant anymore in comparison to car users among all residents. Furthermore, regarding the control variables, the data reveals that fewer differences within the residents' characteristics are significant and that most changes result for the conflicts "Pedestrians are impeded by car traffic and parking."

As a sequence of Table 5, I calculated OLS models for each conflict factor. Table 7 displays the four models for all residents from households with private car ownership. Again, as in Table 5, the explained variances differ between the models and here they are higher for models 2-4 than in the models for all residents. Bicycle ownership and different usage patterns of means of transportation have a similar effect on the perception of the conflicts. The same holds true for the classification into the SSBC model, i.e., except for slight changes in the coefficients' strength, the effects are similar to those for all residents. However, changes occur for some control variables. For instance, here, age is not critical for the awareness of conflicts between cyclists and car traffic. 
Table 6. Mean value comparison of the perception of conflicts for residents with private car ownership

\begin{tabular}{|c|c|c|c|c|}
\hline & $\begin{array}{l}\text { Pedestrians are } \\
\text { impeded by } \\
\text { car traffic and } \\
\text { parking } \\
\mathrm{N}=627 \\
\end{array}$ & $\begin{array}{c}\text { Cyclists are } \\
\text { vulnerable with } \\
\text { respect to car traf- } \\
\text { fic and parking } \\
\mathrm{N}=627\end{array}$ & $\begin{array}{l}\text { Pedestrians are } \\
\text { impeded by } \\
\text { bicycles on the } \\
\text { sidewalk } \\
\mathrm{N}=627\end{array}$ & $\begin{array}{l}\text { Car drivers' per- } \\
\text { ceived conflicts } \\
\text { with others } \\
\mathrm{N}=627\end{array}$ \\
\hline \multicolumn{5}{|l|}{ Stages of the SSBC model } \\
\hline Predecisional stage & $-0.39^{* *}$ & $-0.26^{* *}$ & $0.31^{* *}$ & 0.10 \\
\hline Preactional and actional stages & 0.08 & 0.01 & 0.10 & $0.55^{* *}$ \\
\hline Postactional stage & $0.05^{* *}$ & $0.12^{* *}$ & $-0.22^{* *}$ & $-0.11^{* *}$ \\
\hline \multicolumn{5}{|l|}{ Ownership } \\
\hline Private bicycle ownership & -0.14 & $0.14^{* *}$ & $-0.12^{* *}$ & 0.03 \\
\hline No private bicycle ownership & -0.16 & $-0.69^{* *}$ & $0.54^{* *}$ & 0.01 \\
\hline \multicolumn{5}{|l|}{ Regular use of means of transportation } \\
\hline Car as a driver & $-0.23^{* *}$ & -0.10 & $0.10^{* *}$ & $0.10^{*}$ \\
\hline Public transit & $0.07^{*}$ & -0.09 & 0.04 & 0.03 \\
\hline Bicycle & $-0.02^{* *}$ & $0.17^{* *}$ & $-0.41^{* *}$ & 0.05 \\
\hline \multicolumn{5}{|l|}{ Socio-demographics } \\
\hline Gender (male) & -0.08 & -0.09 & 0.12 & -0.06 \\
\hline Gender (female) & -0.19 & -0.03 & -0.03 & 0.09 \\
\hline Age (18-29 years) & $-0.52^{* *}$ & 0.03 & -0.19 & 0.31 \\
\hline Age (30-64 years) & -0.13 & $0.00^{* *}$ & $-0.06^{* *}$ & 0.03 \\
\hline Age (65+ years) & -0.04 & $-0.36^{* *}$ & $0.55^{* *}$ & -0.09 \\
\hline Families with children $<14$ years & $0.12^{* *}$ & $0.23^{* *}$ & $-0.35^{* *}$ & 0.02 \\
\hline Families without children $<14$ years & $-0.21^{* *}$ & $-0.13^{* *}$ & $0.13^{* *}$ & 0.03 \\
\hline Net monthly income $(<1.000 €)$ & -0.05 & -0.15 & 0.29 & 0.16 \\
\hline $\begin{array}{l}\text { Net monthly income }(1000 € \text { to }< \\
2.500 €)\end{array}$ & -0.13 & -0.06 & 0.06 & 0.06 \\
\hline $\begin{array}{l}\text { Net monthly income }(2.500 € \text { to }< \\
4.000 €)\end{array}$ & -0.12 & 0.01 & -0.02 & -0.04 \\
\hline Net monthly income (> 4.000€) & -0.34 & -0.19 & $-0.21^{*}$ & -0.04 \\
\hline University degree & -0.21 & $0.06^{* *}$ & $-0.19^{* *}$ & $0.13^{*}$ \\
\hline No university degree & -0.06 & $-0.20^{* *}$ & $0.31^{* *}$ & $-0.11^{*}$ \\
\hline $\begin{array}{l}\text { All residents with private cars in their } \\
\text { households }\end{array}$ & -0.14 & -0.06 & 0.03 & 0.03 \\
\hline
\end{tabular}


Table 7. OLS regression models for parking and traffic-related conflicts in the neighborhood for all residents with private cars in their households

\begin{tabular}{|c|c|c|c|c|}
\hline & $\begin{array}{l}\text { Pedestrians are } \\
\text { impeded by } \\
\text { car traffic and } \\
\text { parking }\end{array}$ & $\begin{array}{c}\text { Cyclists are } \\
\text { vulnerable } \\
\text { with respect to } \\
\text { car traffic and } \\
\text { parking }\end{array}$ & $\begin{array}{l}\text { Pedestrians are } \\
\text { impeded by } \\
\text { bicycles on the } \\
\text { sidewalk }\end{array}$ & $\begin{array}{l}\text { Car drivers' per- } \\
\text { ceived conflicts } \\
\text { with others }\end{array}$ \\
\hline \multicolumn{5}{|c|}{ Stages of SSBC [Reference: households with car ownership, stages 1-3] } \\
\hline $\begin{array}{l}\text { Households with car ownership, postactional } \\
\text { stage }(1=\text { yes; } 0=\text { no })\end{array}$ & $0.115^{* *}$ & $0.112^{* *}$ & $-0.129^{* *}$ & $-0.108^{* *}$ \\
\hline \multicolumn{5}{|l|}{ Ownership } \\
\hline Private bicycle ownership $(1=$ yes; $0=$ no $)$ & -0.055 & $0.317^{* * *}$ & -0.021 & -0.005 \\
\hline \multicolumn{5}{|l|}{ Regular ${ }^{l}$ use of means of transportation } \\
\hline Car as a driver $(1=$ yes; $0=$ no $)$ & $-0.085^{* *}$ & -0.009 & 0.051 & 0.069 \\
\hline Public transit $(1=$ yes; $0=$ no $)$ & 0.046 & -0.039 & 0.046 & 0.044 \\
\hline Bicycle $(1=$ yes; $0=$ no $)$ & $0.107^{* *}$ & 0.008 & $-0.295^{* * *}$ & 0.045 \\
\hline \multicolumn{5}{|l|}{ Socio-demographics } \\
\hline Gender $(1$ = male; 0 = female $)$ & $0.082^{* *}$ & -0.022 & 0.053 & -0.056 \\
\hline Age & $0.115^{* *}$ & -0.056 & $0.190^{* * *}$ & -0.068 \\
\hline \multicolumn{5}{|l|}{ Families with children $<14$ years } \\
\hline$(1=$ yes; $0=$ no $)$ & $0.157^{* * *}$ & 0.064 & $-0.063^{*}$ & -0.030 \\
\hline Net monthly income & 0.010 & -0.062 & -0.047 & $-0.073^{*}$ \\
\hline University degree $(1=$ yes; $0=$ no $)$ & $-0.080^{*}$ & 0.039 & $-0.093^{* *}$ & $0.102^{* *}$ \\
\hline $\mathrm{R}^{2}$ & 0.095 & 0.162 & 0.255 & 0.038 \\
\hline corrected $\mathrm{R}^{2}$ & 0.081 & 0.149 & 0.243 & 0.023 \\
\hline F-statistic & $0.000^{* * *}$ & $0.000^{* * *}$ & $0.000^{* * *}$ & $0.007^{* *}$ \\
\hline $\mathrm{N}$ & 627 & 627 & 627 & 627 \\
\hline \multicolumn{5}{|c|}{$\begin{array}{l}\text { Factors from PCA analysis as dependent variables. Beta coefficients are shown. } \\
{ }^{* * *} \mathrm{p}<0.00,{ }^{* *} \mathrm{p}<0.05,{ }^{*} \mathrm{p}<0.10\end{array}$} \\
\hline
\end{tabular}

\section{$5 \quad$ Discussion and conclusion}

The aim of this paper was to examine the residents' perception of conflicts caused by parked cars as one prevalent current land use in an urban neighborhood. The residents most often perceive conflicts in which parked cars impede cyclists and pedestrians. In addition, as pedestrians, the residents often feel threatened when cyclists bike on the sidewalk. The conflicts the residents observe the least often are situations in which bicycle parking lots are on the sidewalks, and the overall risk of an accident as a pedestrian. Moreover, all the conflicts drivers perceive with other traffic participants investigated in this study were observed the least often (H1).

\subsection{The behavior change model as an indicator of conflict perception}

This study discovered that just car ownership does not have an effect on the perception of the conflicts (H2). It revealed, however, that bicycle ownership is critical for the awareness of the conflicts between cyclists and car drivers (H3). Regarding the use of different means of transportation, residents who 
regularly cycle perceive the conflicts "Pedestrians are impeded by car traffic and parking" more often than residents who do not regularly use a bicycle. At the same time, regular car drivers perceive these conflicts less often than residents who do not regularly drive (H4). This is in contrast to the results from Chaurand \& Delhomme (2013) who discovered the perceived risk in road interactions between cyclists and car drivers was higher for drivers than for cyclists. The detailed analysis of the residents with private cars showed partially different effects of the other resident characteristics on the perception of the conflicts. Their bicycle ownership and use patterns of means of transportation stayed similar in their effect compared to all residents (H5). Furthermore, this study revealed that residents who own cars but have a low car use (postactional stage of the SSBC model) perceive the conflicts more often than residents, who were classified into the first three stages of the behavior change model (H6). This suggests that it was helpful to utilize the SSBC as not the ownership of means of transportation but rather the use and intention for behavior change are essential for the perception of the conflicts. These results are different from Harms et al. (2009) who had discovered that one of the resident groups with the highest perception of conflicts for pedestrians were residents from households without private cars.

\subsection{Control variables as critical for the perception of conflicts}

Furthermore, the socio-demographic characteristics, which were created as control variables, have a stronger effect on the perception of the conflicts than expected. For example, age is one of the decisive factors for the perception of most conflicts, except for the conflicts from the car driver's perspective. This is similar to the discovery by Harms et al. (2009), who determined that older people were among the residents with the highest awareness of conflicts with parked cars. In the present case study, the elderly in particular perceive the conflicts "Pedestrians are impeded by car traffic and parking" and they have the lowest percentage of bicycle ownership. Walking is an important means of transportation for older people as they manage up to one third of their trips by walking. Thus, having facilities for their daily needs in walking distance is important for their everyday mobility (Infas \& DLR, 2019; Oswald \& Konopik, 2015; Schwanen \& Paez, 2010; Stjernborg, Emilsson, \& Ståhl, 2014). Consequently, the advocacy group for the elderly should have an interest in separate bike lanes so that pedestrians do not need to share their space with cyclists and so that the latter do not have to swerve on to sidewalks anymore.

While the elderly perceive the conflicts between pedestrians and cars as well as between pedestrians and cyclists, surprisingly, residents from households with children perceive the conflicts pedestrians may experience on sidewalks with cyclists less often. Thus, residents from households with children do not seem to feel at risk from cyclists. Looking at the residents with children in detail, the data reveals that almost two- thirds of the residents in households with children regularly use a bicycle. For residents without children, the majority (56\%) do not cycle regularly. In conclusion, sociodemographic factors seem to be more critical than control variables but illustrate that the ownership and usage of the means of transportation are insufficient to explain the perception of conflicts and there are different resident groups living in the neighborhood.

\subsection{Group-serving bias}

The results suggest that the residents mostly perceive the conflicts in which they could be involved as the injured party (as a pedestrian or cyclist) and they perceive the conflicts in which they could be the originator of the conflict less often (as a cyclist or car driver). In other words, people are biased and they only see those conflicts that they do not cause. King et al. (2012) found similar group-serving bias for liabilities and responsibilities among cyclists and drivers. Similarly, Coughenour, Abelar, Pharr, Chien, and Singh (2020) discovered that whether car drivers yield to pedestrians at crosswalks depends on the person crossing and on the value of the driver's car. 


\subsection{Limitations}

The explained variances $\left(\mathrm{R}^{2}\right)$ of some of the models in Table 5 and Table 7 are small. Hence, the conclusions should be read with careful attention. Besides, it needs to be kept in mind that the survey asked the residents to recall conflicts and their experience during traffic participation. Several authors stress the hedonic treadmill effect and recall bias (Mokhtarian \& Pendyala, 2018; Viegas de Lima et al., 2018). Individuals adapt their experiences to reduce overly positive or negative experiences and remember their experiences as more neutral when asked about them than during the actual moment. Thus, the perception of the conflicts in the moment themselves may be even more extreme, either less intense or more severe.

\subsection{Recommendations for cities and policy makers and further research}

The analysis revealed that the current land use and space allocation in cities lead to conflicts, especially between pedestrians and cyclists with parked cars and parking infrastructure as well as between pedestrians and cyclists themselves. The conflicts in which pedestrians are involved are the most controversial as well as the conflicts between pedestrians and cyclists on sidewalks. So, the data in this study suggests that a separate infrastructure for pedestrians and cyclists could help relieve the conflicts. Therefore, urban neighborhoods could give more space to pedestrians and cyclists, and especially dedicate separate infrastructure for the two groups. Such a redesign could include a reallocation of space, for instance through parking control or extensive priced parking. One way for cities to achieve this could be by reusing onstreet parking space for other purposes like wider sidewalks and bike lanes. In the same neighborhood, it was observed that the acceptance of such measurements is higher than often presumed by city officials and policy makers (Kirschner \& Lanzendorf, 2020a). Moreover, the risk of conflicts can be reduced when distances between destinations are short so that residents can walk, cycle or use public transportation to get to destinations and do not need to drive (Merlin et al., 2020).

Finally, as "mobility and livability are inexorably intertwined" (Cervero, 2009, p. 224), several authors have pointed to the relationship between parking, conflicts, and the quality of life in neighborhoods. For instance, cities can increase their livability by banning parking on sidewalks (Becker, 2016; Goldman \& Gorham, 2006). Thus, we need more research that analyzes the detailed parking-induced conflicts and their relationship with the quality of life in neighborhoods, as well as draw the link for a vision zero for a just, sustainable, and livable city.

\section{Acknowledgements}

This research was funded by the German Ministry of Education and Research for the project "QuartierMobil: Persistence and dynamics within the urban neighbourhood—Strategies for the future of urban mobility" [Grant number 01UR1702A].

I would like to thank the residents of Frankfurt-Bornheim for their participation. Furthermore, I am very grateful to Martin Lanzendorf for his support, to Andreas Blitz for the discussions and the feedback, to Caroline Rozynek for the info about the mobility of older people, and to Alison Hindley Chatterjee for the language proof. 


\section{References}

Ajzen, I. (1991). The theory of planned behavior. Organizational Behavior and Human Decision Processes, 50, 179-211.

Alrutz, D., \& Bohle, W. (2001). Flächenbedarf des Fußverkehrs und des Aufenthalts auf Gehwegen. In T. Bracher et al. (Eds.), Handbuch der kommunalen verkehrsplanung (pp. 1-19). Berlin: Wichmann Verlag.

Bamberg, S. (2013). Applying the stage model of self-regulated behavioral change in a car use reduction intervention. Journal of Environmental Psychology, 33, 68-57. https://dx.doi.org/10.1016/j. jenvp.2012.10.001

Bamberg, S. (2012). Wie funktioniert verhaltensveränderung? Das MAX-selbstregulationsmodell. In M. Stiewe \& M. Reutter (Eds), Mobilitätsmanagement: Wissenschaftliche grundlagen und wirkungen in der praxis (pp. 76-101). Essen: Klartext Verlag.

Banister, D. (2008). The sustainable mobility paradigm. Transport Policy, 15, 73-80. https://doi. org/10.1016/j.tranpol.2007.10.005

Becker, U. J. (2016). Grundwissen verkehrsökologie. Grundlagen, handlungsfelder und maßnahmen für die verkehrswende. Munich: Oekom Verlag.

Binson, D., Canchola, J. A. \& Catania, J. A. (2000). Random selection in a national telephone survey: A comparison of the kish, next-birthday, and last-birthday method. Journal of Official Statistics, 16(1), 53-59.

Blitz, A., Busch-Geertsema, A., \& Lanzendorf, M. (2020). More cycling, less driving? Findings of a cycle street intervention study in the Rhine-Main metropolitan region. Sustainability, 12(805), 1-25. https://doi.org/10.3390/su12030805

Bracher, T. (2014). Fahrrad-und fußverkehr: Strukturen und potentiale. In O. Schwedes et al. (Eds.). Handbuch verkehrspolitik (pp. 1-22). Wiesbaden: VS Verlag für Sozialwissenschaften.

Cervero, R. (2009). Transport infrastructure and global competitiveness: Balancing mobility and livability. Annals of the American Academy of Political and Social Science, 626(1), 210-225. https:// doi.10.1177/0002716209344171

Chataway, E. S., Kaplan, S., Nielsen, T. A. S., \& Prato, C. G. (2014). Safety perceptions and reported behavior related to cycling in mixed traffic: A comparison between Brisbane and Copenhagen. Transportation Research Part F, 23, 32-43. https://dx.doi.org/10.1016/j.trf.2013.12.021

Chaurand, N. \& Delhomme, P. (2013). Cyclists and drivers in road interactions: A comparison of perceived crash risk. Accident Analysis and Prevention, 50, 1176-1184. https://dx.doi.org/10.1016/j. aap.2012.09.005

Chester, M., Horvath, A., \& Madanat, S. (2011). Parking infrastructure and the environment. Access, $39,28-33$.

City of Frankfurt, Referat mobilitäts-und verkehrsplanung. (2014). Parkkonzept Bornheim - erhebungsergebnisse. Frankfurt: Frankfurt am main.

City of Frankfurt, Bürgeramt Statistik und Wahlen. (2019a). Materialien zur stadtbeobachtung (No. 28). Retrieved from https://frankfurt.de/service-und-rathaus/zahlen-daten-fakten

City of Frankfurt, der Magistrat. (2019b). Bericht des magistrats an die stadtverordnetenversammlung (B299). Retrieved from https://www.stvv.frankfurt.de/PARLISLINK/ DDW?W=DOK_ NAME=\%27B_299_2019\%27

City of Frankfurt, Stadtvermessungsamt (2020). GeoInfo Frankfurt. Retrieved from https://geoinfo. frankfurt.de/index.html

Coughenour, C., Abelar, J., Pharr, J., Chien, L.-C., \& Singh, A. (2020). Estimated car cost as a predic- 
tor of driver yielding behaviors for pedestrians. Journal of Transport \& Health, 16(100831). https:// doi.10.1016/j.jth.2020.100831

Cox, P. (2012). A denial of our boasted civilization: Cyclists' views on conflicts over road use in Britain, 1926-1935. Transfers 2(3), 4-30. https://doi.10.3167/trans.2012.020302

Culver, G. (2018). Death and the car: On (auto)mobility, violence, and injustice. $A C M E, 17(1), 144$ 170.

DiClemente, C. C., \& Prochaska, J. O. (1982). Self-change and therapy change of smoking behavior: A comparison of processes of change in cessation and maintenance. Addictive Behaviors, 7, 133-142. https://doi.org/10.1016/0306-4603(82)90038-7

Diekmann, A. (2017). Empirische sozialforschung — grundlagen, methoden, anwendungen. Reinbek bei Hamburg: Rowohlt.

Dürr, S., \& Simon-Philipp, C. (2013). Stadterneuerung und öffentlicher raum. Wohnraum stadt strategien, projekte. In K. Altrock et al. (Eds.), Jahrbuch atadterneuerung 2013 - das ende der behutsamkeit? (pp. 303-315). Berlin: TU Berlin.

Ewing, R. \& Dumbaugh, E. (2009). The built environment and traffic safety: A review of empirical evidence. Journal of Planning Literature, 23(4), 347-367. https://doi.10.1177/0885412209335553

Federal Statistical Office. (2020, February 27). Press release No. 061. Retrieved from https://www.destatis.de/EN/Press/2020/02/PE20_061_46241.html

Field, A. (2018). Discovering statistics using IBM SPSS statistics (5th ed.). London: Sage Publications Ltd

Findley, D. J., Nye, T. S., Lattimore, E., Swain, G., Bhat, S. K. P. \& Foley, B. (2020). Safety effects of parking maneuvers. Transportation Research Part F: Traffic Psychology and Behavior, 69, 301-310. https://doi.10.1016/j.trf.2020.02.002

Fuller, W. A. (2009). Sampling statistics. Hoboken: John Wiley \& Sons.

Gehl, J. (2010). Public spaces for changing life. In A. Havermann \& K. Selle (Eds.), Plätze, parks \& co: Stadträume im wandel - analysen, positionen und konzepte (pp. 375-384). Detmold: Rohn Verlag.

Gehl, J. (2015). Cities for people. Washington, DC: Island Press

Gifford, R. \& Steg, L. (2007). The impact of automobile traffic on quality of life. In R. Gifford \& L. Steg (Eds.), Threats from car traffic to the quality of urban life: Problems, causes and solutions (pp. 33-51). Amsterdam: Elsevier.

Goldman, T. \& Gorham, R. (2006). Sustainable urban transport: Four innovative directions. Technology in Society, 28(1-2), 261-273. https://doi.10.1016/j.techsoc.2005.10.007

Gössling, S., Schröder, M., Späth, P. \& Freytag, T. (2016). Urban space distribution and sustainable transport. Transport Reviews, 36(5), 659-679. https://doi.org/10.1080/01441647.2016.1147101

Harms, S., Kviese, R., Dombrowski, F., Höer, S., Kussatz, A., \& Rosenau, E. (2009). Parkraumprobleme in wachsenden stadtteilen. Anwohnerbefragung und evaluation freiwilliger verhaltensänderungen zur lösung des parkraumproblems in Leipzig-Schleußig (UFZ-Diskussionspapiere). Leipzig: HelmholtzZentrum für Umweltforschung.

Infas (Institut für Angewandte Aozialwissenschaft) \& DLR (Deutsches Zentrum für Luft- und Raumfahrt). (2019). Mobilität in Deutschland - kurzreport. Retrieved from http://www.mobilitaet-indeutschland.de/pdf/infas_Mobilitaet_in_Deutschland_2017_Kurzreport.pdf

Jacobsen, P. L., Racioppi, F. \& Rutter, H. (2009). Who owns the roads? How motorized traffic discourages walking and bicycling. Injury Prevention, 15, 369-373. https://doi.10.1136/ip.2009.022566

King, M. J., Wood, J. M., Lacherez, P. F., \& Marszalek, R. P. (2012). Optimism about safety and group-serving interpretations of safety among pedestrians and cyclists in relation to road use in general and under low light conditions. Accident Analysis and Prevention, 44, 154-159. https://doi. org/10.1016/j.aap.2010.12.003 
Kirschner, F. (2019). Methodik zur haushaltsbefragung "quartiersentwicklung und mobilität in Frankfurt-Bornheim (Arbeitspapiere zur mobilitätsforschung, 20). Frankfurt: Goethe University Frankfurt am Main. Retrieved from http://publikationen.ub.uni-frankfurt.de/frontdoor/index/index/ $\operatorname{docId} / 46487$.

Kirschner, F. \& Lanzendorf, M. (2020a). Support for innovative on-street parking policies: Empirical evidence from an urban neighborhood. Journal of Transport Geography, 85, 102726. https://doi. org/10.1016/j.jtrangeo.2020.102726

Kirschner, F. \& Lanzendorf, M. (2020b). Parking management for promoting sustainable transport in urban neighborhoods. A review of existing policies and challenges from a German perspective. Transport Reviews, 40(1), 54-75. https://doi.org/10.1080/01441647.2019.1666929

Kuhnimhof, T., Buehler, R., Wirtz, M. \& Kalinowska, D. (2012). Travel trends among young adults in Germany: Increasing multimodality and declining car use for men. Journal of Transport Geography, 24, 443-450. https://dx.doi.org/10.1016/j.jtrangeo.2012.04.018

Le, H. T. K., Buehler, R., \& Hankey, R. (2019). Have walking and bicycling increased in the US? A 13year longitudinal analysis of traffic counts from 13 metropolitan areas. Transportation Research Part D, 69, 329-345. https://doi.org/10.1016/j.trd.2019.02.006

Litman, T. (2019). Well measured. Developing indicators for sustainable and livable transport planning. Victoria, BC: Victoria Transport Policy Institute.

Malin, F., Silla, A., \& Mladenović, M. (2020). Prevalence and factors associated with pedestrian fatalities and serious injuries: Case Finland. European Transport. Reseach Review, 12(1), 1-17. https://doi. org/10.1186/s12544-020-00411-z

Manville, M., \& Pinski, M. (2020). Parking behavior: Bundled parking and travel behavior in American cities. Land Use Policy, 91, 103853. https://doi.10.1016/j.landusepol.2019.02.012

Manville, M., \& Shoup, D. (2018). People, parking, and cities. In D. Shoup (Ed.). Parking and the city (pp. 74-80). New York: Routledge.

Mattioli, G., Roberts, C., Steinberger, J. K., \& Brown, A. (2020). The political economy of car dependence: A systems of provision approach. Energy Research \& Social Science, 66, 101486. https:// doi.10.1016/j.erss.2020.101486

Merlin, L. A., Cherry, C. R., Mohamadi-Hezaveh, A., \& Dumbaugh, E. (2020). Residential accessibility's relationships with crash rates per capita. Journal of Transport and Land Use, 13(1), 113-128. https://dx.doi.org/10.5198/jtlu.2020.1626

Mokhtarian, P. L. \& Pendyala, R. M. (2018). Travel satisfaction and wellbeing. In M. Friman, D. Ettema \& L. E. Olsson (Eds.), Quality of life and daily travel (pp. 17-39). Cham: Springer International Publishing. https://doi.org/10.1007/978-3-319-76623-2_2

Nello-Deakin, S. (2019). Is there such a thing as a 'fair' distribution of road space? Journal of Urban Design, 24(5), 698-714. https://doi.org/10.1080/13574809.2019.1592664

Norton, P. D. (2008). Fighting traffic: The dawn of the motor age in the American city. Cambridge, MA: MIT Press.

Notz, J. N. (2017). Die privatisierung des öffentlichen raums durch parkende kfz. Von der tragödie einer allmende - ̈̈ber ursache, wirkung und legitimation einer gemeinwohlschädigenden regulierungspraxis (IVP-discussion paper 1/2017). Berlin: TU Berlin.

OECD (Organization for Economic Co-Operation and Development) (2020, April 16). What are equivalence scales? OECD project on income distribution and poverty. Retrieved from http://www. oecd.org/els/soc/OECD-Note-EquivalenceScales.pdf

Oswald, F. \& Konopik, N. (2015). Bedeutung von außerhäuslichen aktivitäten, nachbarschaft und stadtteilidentifikation für das wohlbefinden im alter. Zeitschrift für Gerontologie und Geriatrie, 5(48), 
401-407. https://doi.org/10.1007/s00391-015-0912-1

Pai, C.-W. (2011). Overtaking, rear-end, and door crashes involving bicycles: An empirical investigation. Accident Analysis and Prevention, 43, 1228-1235. https://doi.org/10.1016/j.aap.2011.01.004

Prochaska, J. O., \& DiClemente, C. C. (1983). Stages and processes of self-change of smoking: Toward an integrative model of change. Journal of Consulting and Clinical Psychology, 51(3), 390-395. https://doi.org/10.1037/0022-006X.51.3.390

Schlossberg, M. \& Amos, D. (2015). Rethinking residential on-street parking. In E. Talen (Ed.), Retrofitting sprawl: Addressing seventy years of failed urban form (pp. 181-198). Athens, GA: University of Georgia Press.

Schwanen, T., \& Páez, A. (2010). The mobility of older people - an introduction. Journal of Transport Geography, 18, 591-595. https://doi.org/10.1016/j.jtrangeo.2010.06.001

Schwartz, S. H. (1977). Normative influences on altruism. In L. Berkowitz (Ed.), Advances in experimental social psychology (pp. 221-279). New York: Academic Press.

Stevens, J. P. (2002). Applied multivariate statistics for the social sciences (5th ed.). New York: Routledge.

Stjernborg, V., Emilsson, U. M. \& Ståhl, A. (2014). Changes in outdoor mobility when becoming alone in the household in old age. Journal of Transport \& Health, 1, 9-16.

Vuchic, V. R. (2010). Transportation for livable cities: Problems, obstacles and successful solutions. In G. L. Ooi \& B. Yuen (Eds.), World cities: Achieving livability and vibrancy (pp. 105-130). Singapore: World Scientific Publishing.

Viegas de Lima, I., Abou-Zeid, M., Kutadinata, R., Nacidi, Z., Winter, S., Zhao, F. \& Ben-Akiva, M. (2018). Dynamic modeling of activity happiness: An investigation of the intra-activity hedonic treadmill. In M. Friman, D. Ettema \& L. E. Olsson (Eds.), Quality of life and daily travel (pp. 95118). Cham: Springer International Publishing. https://doi.org/10.1007/978-3-319-76623-2_6

Weinberger, R. (2018). Parking mismanagement: An Rx for congestion. In D. Shoup (Ed.), Parking and the city (pp. 101-108). New York: Routledge.

Weinberger, R., \& Jacobson, L. (2014). Parking in Guangzhou: Principles for congestion reduction and improving quality of life in a growing city. In S. Ison \& C. Mulley (Eds.), Parking: Issues and policies (pp. 381-407). Howard House, UK: Emerald Group Publishing.

Wood, J. M., Lacherez, O. F., Marszalek, R. P. \& King, M. J. (2009). Drivers' and cyclists' experiences of sharing the road: Incidents, attitudes and perceptions of visibility. Accident Analysis and Prevention, 41, 772-776. https://doi.org/10.1016/j.aap.2009.03.014 